\title{
NIAT BELI SEPATU MEREK LOKAL OLEH GENERASI MUDA: PENGARUH CONSUMER ETHNOCENTRISM, PERCEIVED QUALITY, PERCEIVED PRICE, DAN PERCEIVED BRAND IMAGE
}

\author{
Lailatul Maghfiroh \\ Universitas Negeri Surabaya \\ lailatul.17080574033@mhs.unesa.ac.id \\ Sri Setyo Iriani \\ Universitas Negeri Surabaya \\ srisetyo@unesa.ac.id
}

Abstract

Indonesia is one of the top 4 world footwear producers. On the other hand, there are many well-known foreign brand shoes in Indonesia. Ventela is one of a famous shoes local brand in Indonesia. The local consumers have preferences concerning the shoe producer country of origin. Local people prefer to buy local brand shoes if they have an ethnocentric taste and good perceptions about the local brand. Therefore, this study aims to determine the effect of consumer ethnocentrism, perceived quality, perceived price, and perceived brand image toward a willingness to buy Ventela shoes. The survey was conducted using an online questionnaire and collected data from 205 young generations. Multiple linear regression in SPSS software was used to analyze the collected data. This study shows that consumer ethnocentrism, perceived quality, and perceived price significantly affected willingness to buy. Meanwhile, the perceived brand image had no significant effect on willingness to buy. Further research is suggested to compare several local fashion brands with different positioning. The results of this study can be used as input for Ventela shoes in facing business competition and business development by paying attention to the variables used.

Keywords: consumer ethnocentrism; perceived brand image; perceived price; perceived quality; local brand

\section{PENDAHULUAN}

Generasi muda memiliki perilaku mengikuti tren masa kini atau up to date, menarik, atraktif, lebih berani menampilkan diri, percaya diri dalam berpenampilan, takut ketinggalan mode, dan santai namun modis (Sumarwan, 2015). Fashion merefleksikan gaya berbusana, gaya aksesori, kosmetik, gaya rambut dan lain-lain yang dapat menunjang penampilan seorang individu (Setiawan, 2020). Fashion ditunjang oleh hal-hal yang dapat menambah apiknya fashion yang digunakan, salah satunya sepatu. Macam-macam model sepatu antara lain flat shoes, boots, oxford, heels, sneakers, dan lainlain yang memiliki fungsi pakai yang berbeda-beda, tergantung pada kebutuhan fashion dan gaya busana (Anggraini, 2020).

Sejalan dengan hal tersebut, Indonesia masuk dalam empat besar produsen alas kaki dunia di bawah Tiongkok, India, dan Vietnam. Dengan produksi 1,41 miliar pasang sepatu pada 2018, Indonesia berkontribusi sekitar 4,6\% terhadap total produksi sepatu dunia (Kementerian Perindustrian Republik Indonesia, 2019). Pada 2018, Indonesia menduduki peringkat enam negara eksportir sepatu sedunia. Jumlah itu meningkat dua kali lipat dari 2017 (Nor, 2019). Industri alas kaki menjadi salah satu sektor yang mendapat prioritas pengembangan dari pemerintah di Indonesia karena tergolong padat karya yang berpeluang ekspor sehingga akan mampu memberikan kontribusi pada perekonomian nasional. Pertumbuhan kelompok industri alas kaki di Indonesia mengalami peningkatan dari 2017 sebesar 2,22\% dan mampu tumbuh hingga 9,42\% pada 2018 (Kementerian Perindustrian Republik Indonesia, 2019).

Salah satu jenis sepatu yang terkenal di Indonesia adalah sneakers. Sneakers merupakan jenis sepatu dengan sol fleksibel yang terbuat dari karet, kulit, sintetis maupun kain (SepatuSneaker.Com, 2020). Peningkatan peminat sneakers berada pada angka 50\% hingga 70\% pada 2016-2017. Hal ini 
Lailatul Maghfiroh \& Sri Setyo Iriani. Niat Beli Sepatu Merek Lokal oleh Generasi Muda: Pengaruh Consumer Ethnocentrism, Perceived Quality, Perceived Price, dan Perceived Brand Image

dibuktikan saat penyelenggaraan Jakarta Sneaker Day (JDS) 2017, yang semula hanya menargetkan 7.000 pengunjung tetapi meningkat hingga 15 ribu pengunjung (Hasibuan, 2018).

Sejumlah merek lokal ternama tidak masuk dalam kategori lima besar peraih pangsa pasar alas kaki di Indonesia disebabkan keberadaan merek populer kelas dunia di pasar sepatu Indonesia. Pada 2017, merek sepatu asing yang sukses meraih pangsa pasar terbesar di Indonesia didominasi oleh Bata (27\%), Nike (18\%), Converse All Star (17\%), dan Adidas (5,4\%) dalam kategori sepatu casual. Sedangkan dalam kategori sepatu sport, merek yang mendominasi antara lain Nike (30\%), Adidas (23\%), Reebok (6,3\%), dan Bata (4,3\%) (Silitonga, 2018). Dalam Top Brand Award fase 1 tahun 2020 kategori sepatu casual, Bata berada pada urutan pertama dengan index sebear $12.5 \%$, yang kedua adalah Carvil (10.1\%), kemudian Ardiles (7.5\%), Fladeo (5.8\%), dan Nike (4.5\%). Bata telah menduduki urutan teratas sejak 2015 yang mengartikan bahwa peraih pasar sepatu terbesar di Indonesia diraih oleh merek asing (Top Brand Award, 2020).

Meskipun sepatu merek lokal tidak termasuk dalam kategori Top Brand Awards, sepatu merek lokal dapat bersaing di pasar Indonesia karena harga sepatu merek asing semakin mahal. Selain itu, desain dan bahan sepatu merek lokal bisa menyaingi sepatu merek internasional (Mediaini, 2020). Semakin mahalnya sepatu merek asing juga disebabkan oleh peraturan baru tentang ambang batas nilai barang impor yang bebas tarif bea masuk dari sebelumnya US\$ 75 per kiriman menjadi US\$ 3 per kiriman khusus untuk tiga produk favorit masyarakat, yaitu tas, sepatu dan produk tekstil seperti baju yang mulai diberlakukan pada 2020 (Direktorat Jenderal Bea dan Cukai, 2020). Hal ini tentunya berdampak baik bagi produsen sepatu merek lokal. Ada banyak merek sepatu lokal yang terkenal di Indonesia, di antaranya Ventela, Piero, Poison Street, League, Buccheri, Tomkins, Saint Barkley, Compass, Tomkins, Sagara Boots, NAH Project, Exodos 57, Yongki Komaladi, Geoff Max Footwear, Eagle, Ardiles, Thanksinsomnia, Kodachi, Wakai, Brodo, Carvil dan PVN Shoes (Firdha, 2020).

Ventela merupakan salah satu sepatu merek lokal yang mulai dikenalkan pada tahun 2017 dan sedang populer di kalangan milenial (Anteraja, 2020). Kelebihan yang dimiliki sepatu Ventela yaitu memiliki insole Ultralite Foam Insole yang empuk dan nyaman, jahitan yang rapi serta kualitas sol sepatunya yang bagus sehingga tidak akan cepat rusak. Selain itu, sepatu ini telah memiliki pabrik sendiri sehingga bahan dan proses produksinya benar-benar terjamin selain kenyamanan pemakai dan estetika sepatu (Aris, 2021). Pra penelitian telah dilakukan pada 30 responden berusia 15-24 tahun. Responden diminta menjawab pertanyaan terkait merek-merek sepatu lokal yang pernah dibeli pada satu tahun terakhir atas pilihan 31 merek sepatu lokal yang telah disediakan. Hasil pra-penelitian menunjukkan bahwa merek sepatu lokal yang paling banyak dibeli pada tahun 2020 adalah Nevada, kedua adalah Ventela, dan diikuti tiga merek yang selanjutnya yaitu Yongki Komaladi, Ardiles, dan Compass.

Mendukung merek lokal tidak hanya merupakan suatu hal yang penting sebagai wujud kecintaan terhadap negeri. Upaya membantu mengembangkan produk-produk dalam negeri dan kearifan lokal juga dilakukan karena produk lokal memiliki desain dan kualitas yang tidak kalah dari produk luar negeri (Dzikrullah, 2019). Beberapa di antara upaya pemerintah dalam memajukan dan mendukung berkembangnya merek lokal antara lain dengan menyelenggarakan beberapa webinar mengenai bisnis lokal, mendukung kampanye-kampanye untuk mendorong penjualan produk-produk lokal dan mencetuskan peringatan hari belanja produk lokal (Kementerian Luar Negeri Republik Indonesia, 2020; Kementerian Komunikasi dan Informatika, 2020; Alaydrus, 2021).

Produk merek lokal juga menjadi perhatian peneliti. Beberapa penelitian membahas mengenai niat beli produk lokal yang ada di negara berkembang, di antaranya melibatkan variabel consumer ethnocentrism, perceived quality, perceived price, perceived brand image, animosity, product judgement, dan product evaluation (Yen, 2018; Fernández-Ferrín et al., 2015; Cui et al., 2012; Souiden et al., 2018). Penelitian-penelitian tersebut membuka peluang untuk meneliti lebih lanjut mengenai niat beli produk merek lokal yang dipengaruhi oleh consumer ethnocentrism, perceived quality, perceived price, dan perceived brand image. 
Niat beli masyarakat Indonesia terhadap sepatu merek lokal mengalami peningkatan di tengah-tengah merebaknya sepatu merek global yang memiliki nama besar di Indonesia (Hagiworo, 2021). Lokalitas merek atau produk menjadi hal utama yang memengaruhi niat beli konsumen (Hoskins et al., 2020). Dalam membeli produk dalam negeri, konsumen di negara berkembang juga dipengaruhi oleh etnosentrisme (Yen, 2018). Hal ini bisa terjadi pada produk-produk lokal dan asing yang terkesan serupa dan memiliki banyak kesamaan. Kalaupun tidak ada perbedaan antarproduk, produk dalam negeri akan dinilai dan dipersepsikan lebih positif (Lee et al., 2016).

Consumer ethnocentrism merupakan salah satu faktor yang memengaruhi kemauan untuk membeli produk merek lokal. Consumer ethnocentrism sangat relevan ketika konsumen memilih antara produk dalam negeri dan impor luar negeri (Cui et al., 2012). Consumer ethnocentrism mengacu pada kepercayaan konsumen bahwa membeli produk buatan luar negeri adalah perbuatan yang tidak pantas, tidak bermoral, dan dapat merugikan bisnis dan lapangan kerja nasional. Selanjutnya, etnosentrisme konsumen tidak hanya menjadi pendorong kewajiban moral untuk membeli produk buatan lokal tetapi juga menjadi penentu persepsi produk atas produk lokal (Teng, 2019). Di negara berkembang, konsumen cenderung membeli produk dalam negeri dan menolak produk impor karena etnosentrisme. Oleh karena itu, dapat diasumsikan bahwa hubungan antara etnosentrisme konsumen dan kesediaan untuk membeli produk dalam negeri berkorelasi positif di negara berkembang (Yen, 2018).

Lebih lanjut, perceived quality juga menjadi pendorong utama kemauan membeli konsumen dari segi kualitas. Perceived quality memberikan nilai kepada konsumen dengan memberi mereka alasan untuk membeli dan dengan membedakan merek dari merek pesaing, yaitu antara merek lokal dan asing (Asshidin et al., 2016). Perceived quality terkadang digunakan sebagai representasi dari citra merek. Konsumen mungkin bersedia membeli produk dalam negeri jika mereka menganggapnya berkualitas tinggi. Dengan demikian, dapat diasumsikan bahwa perceived quality akan berdampak positif pada kesediaan untuk membeli produk dalam negeri bagi konsumen di negara berkembang (Yen, 2018).

Selain itu, faktor harga dianggap sebagai prediktor penting apakah konsumen akan memiliki kemauan untuk membeli. Ketika harga yang dipersepsikan terlalu tinggi, keinginan konsumen untuk membeli berkurang, tetapi jika harga yang dipersepsikan masuk akal, keinginan konsumen untuk membeli meningkat (Son \& Jin, 2019; Mannan et al., 2019). Konsumen menganggap produk dalam negeri memiliki harga yang rendah. Persepsi ini dapat mendorong mereka untuk membeli produk dalam negeri karena kekhawatiran biaya ekonomi. Sebaliknya, harga tinggi dapat menghalangi konsumen untuk membeli produk dalam negeri (Yen, 2018). Oleh karena itu, perceived price yang positif dapat meningkatkan niat beli konsumen (Mannan et al., 2019).

Niat beli konsumen juga dapat dipengaruhi oleh perceived brand image yang merupakan faktor penting yang memengaruhi persepsi subjektif pelanggan dan perilaku konsekuen. Semakin besar perceived brand image produk dalam negeri dalam benak konsumen maka semakin besar pula kemauan untuk membelinya. Perceived brand image yang lebih kuat mengarah pada niat beli yang lebih positif terhadap produk bermerek dan atributnya. Perceived brand image memengaruhi kesediaan konsumen untuk membeli terlepas dari produk dalam negeri atau impor (Yen, 2018).

Penelitian ini dilakukan dengan tujuan mengetahui pengaruh consumer ethnocentrism, perceived quality, perceived price, dan perceived brand image terhadap niat beli.

\section{KAJIAN PUSTAKA DAN PENGEMBANGAN HIPOTESIS}

\section{Merek Lokal}

"Lokal" diartikan sebagai tempat di mana kantor pusat merek berada (Hoskins et al., 2020). Bukti penelitian terkini juga menunjukkan bahwa konsumen lebih memilih merek dengan keterikatan lokal yang kuat (Roy \& Chau, 2011). Merek lokal menjual produknya di wilayah geografis yang kecil atau 
Lailatul Maghfiroh \& Sri Setyo Iriani. Niat Beli Sepatu Merek Lokal oleh Generasi Muda: Pengaruh Consumer Ethnocentrism, Perceived Quality, Perceived Price, dan Perceived Brand Image

terbatas pada suatu negara (Teng, 2019) dan dikembangkan untuk disesuaikan dengan kebutuhan unik dan keinginan pasar lokal (Lomelí et al., 2019).

Lokalitas adalah klaim keaslian yang kuat untuk dibuat oleh perusahaan, karena dengan mudah dan kontras dengan apa yang bukan lokal. Perusahaan menggunakan status lokal secara sosial atau kognitif untuk menghubungkan produk ke konsumen dengan menandakan bahwa produk tersebut secara unik sesuai dengan selera tempat konsumen. Melalui produk lokal, konsumen dapat mengekspresikan identitas dirinya dan dapat berproses secara kolektif dengan lingkungan sekitarnya (Hoskins et al., 2020).

\section{Generasi Muda}

Generasi muda yaitu generasi yang berada pada rentang usia 15-24 tahun (United Nation, 2007). Menurut Clow \& Baack (2018), usia tersebut memiliki karakteristik suka membelanjakan uang untuk pakaian, kendaraan, menempuh pendidikan di perguruan tinggi, dan elektronik. Mereka menyukai keterlibatan dan interaksi melalui media sosial dan ingin menjadi konsumen aktif atas sebuah merek, bukan hanya konsumen pasif. Dalam penelitian Prince et al. (2019), individu-individu yang lahir pada pertengahan 1990-an hingga awal 2000-an merupakan generasi yang berpendidikan, melek teknologi, inovatif, kreatif, kooperatif, inovatif, multitasker, dan berkembang. Pada penelitian ini, niat beli dikaitkan dengan kemauan generasi muda dalam membeli sepatu sebagai produk fashion bermerek lokal yang dipengaruhi oleh consumer ethnocentrism, perceived quality, perceived price, dan perceived brand image.

\section{Niat Beli}

Niat beli dapat diartikan sebagai kemungkinan yang dirasakan untuk membeli produk (Souiden et al.,2018). Niat beli didefinisikan sebagai kemungkinan pembeli bermaksud membeli produk (Meshreki et al., 2018). Meskipun penelitian tentang niat beli produk dalam negeri telah diteliti di negara maju dan berkembang, cara kerjanya berbeda. Konsumen di negara berkembang, seperti Cina, India dan Rusia, sangat ingin membeli merek negara mereka sendiri dan bahwa konsumen ini percaya bahwa etnosentrisme mendorong konsumen untuk membeli produk dalam negeri (Yen, 2018).

\section{Consumer Ethnocentrism}

Consumer ethnocentrism didefinisikan sebagai keyakinan yang dianut oleh konsumen mengenai kesesuaian dan moralitas pembelian produk buatan luar negeri (Fernández-Ferrín et al., 2015). Consumer ethnocentrism yang tinggi membuat konsumen lebih memilih untuk membeli produk dalam negeri daripada produk luar negeri dan melihat produk dalam negeri lebih unggul daripada yang diproduksi di negara lain. Produk lokal cenderung dipilih konsumen daripada produk luar negeri jika dibandingkan dengan baik pada semua atribut. Maka, masuk akal untuk mengasumsikan bahwa konsumen memilih produk dalam negeri daripada produk luar negeri karena faktor consumer ethnocentrism atau prasangka terhadap produk luar negeri (Lee et al., 2016).

Sejumlah penelitian menangkap hubungan positif consumer ethnocentrism dengan perilaku pembelian lokal. Penelitian lain menganalisis sikap negatif terhadap pembelian produk luar negeri. Consumer ethnocentrism menggambarkan pandangan tentang hal-hal di mana kelompoknya sendiri adalah pusat dari segalanya, dan semua yang lain diskalakan dan dinilai dengan mengacu pada kelompoknya (Abdelwahab et al., 2020; Khan et al., 2019; Prince et al., 2019).

Consumer ethnocentrism sering kali melibatkan sikap yang tidak menguntungkan tentang produk impor dan sikap kognitif, emosional, dan normatif konsumen yang menguntungkan terhadap produk dalam negeri. Consumer ethnocentrism menilai kelompok mereka sendiri atau budaya mereka sendiri lebih tinggi dari orang lain. Konsumen dengan etnosentrisme yang kuat menganggap pembelian produk impor sebagai perilaku non-etnis, sesuatu yang merugikan perekonomian negara sendiri dan menyebabkan hilangnya lapangan kerja (Prince et al., 2019; Xin \& Seo, 2019). Sikap pembelian terhadap barang asing berkorelasi negatif dengan etnosentrisme. Selain itu, konsumen dengan etnosentrisme tinggi lebih menonjolkan ciri positif produk dalam negeri sekaligus merendahkan ciri positif produk impor. Jenis etnosentrisme ini dapat menyebabkan konsumen meremehkan produk impor dan melebih-lebihkan produk dalam negeri (Xin \& Seo, 2019). 
Consumer ethnocentrism mengacu pada kepercayaan konsumen bahwa membeli produk buatan luar negeri adalah perbuatan yang tidak pantas, tidak bermoral, dan dapat merugikan bisnis dan lapangan kerja nasional. Selanjutnya, consumer ethnocentrism tidak hanya menjadi pendorong kewajiban moral untuk membeli produk buatan lokal tetapi juga menjadi penentu persepsi produk atas produk lokal. Sikap etnosentris yang kuat dapat menyebabkan peringkat produk dalam negeri lebih tinggi dan bahkan konsumen akan mau membayar harga yang lebih mahal untuk membeli produk lokal (Teng, 2019). Namun, Shu \& Strombeck (2017) mengemukakan bahwa merek lokal dianggap lebih tradisional karena hubungannya dengan budaya lokal. Sebaliknya, beberapa konsumen di negara berkembang menganggap bahwa merek global lebih baik dari merek lokal.

\section{Perceived Quality}

Yen (2018) mendefinisikan perceived quality sebagai penilaian konsumen tentang keunggulan suatu produk. Perceived quality adalah hal utama yang memengaruhi keinginan untuk membeli, terlepas dari apakah itu produk domestik atau impor. Konsumen mungkin bersedia membeli produk dalam negeri jika mereka menganggapnya berkualitas tinggi. Dengan demikian, dapat diasumsikan bahwa perceived quality akan berdampak positif pada niat beli produk lokal bagi konsumen di negara berkembang.

Perceived quality dijadikan salah satu dasar penilaian tentang keunggulan keseluruhan yang dimiliki suatu produk (Srivastava \& Sharma, 2013). Perceived quality juga dapat digunakan sebagai cerminan dari citra merek. Ini didefinisikan sebagai penilaian konsumen tentang keunggulan produk secara keseluruhan (Souiden et al., 2018). Yan et al. (2019) mengemukakan dalam penelitiannya bahwa perceived quality berpengaruh positif terhadap niat beli konsumen

Perceived quality mencerminkan keyakinan konsumen tentang apakah kualitas produk itu baik. Perceived quality juga memberikan nilai produk kepada konsumen supaya memiliki alasan untuk membeli dan membedakan merek dari merek pesaing. Perceived quality menjadi evaluasi konsumen atas keunggulan merek secara keseluruhan berdasarkan petunjuk intrinsik (kinerja dan daya tahan) dan petunjuk ekstrinsik (nama merek) (Asshidin et al., 2016) serta sebuah cara di mana pelanggan memandang ekuitas merek produk dan keunggulan keseluruhan dibandingkan dengan alternatif yang tersedia (Beneke et al., 2013).

\section{Perceived Price}

Harga dianggap sebagai faktor pengaruh utama konsumen dalam memilih untuk membeli suatu produk. Harga merupakan biaya yang paling dipertimbangkan oleh konsumen dan berperan penting dalam pengambilan keputusan pembelian (Sun et al., 2019; Park \& Jang, 2019). Perceived price didefinisikan sebagai proses di mana konsumen menginterpretasikan informasi tentang harga dan nilai atribut untuk barang atau jasa. Ketika perceived price terlalu tinggi, maka niat beli konsumen berkurang, tetapi jika perceived price masuk akal, maka niat beli konsumen meningkat (Son \& Jin, 2019).

Perceived price merupakan persepsi konsumen tentang harga suatu produk yang dibandingkan dengan merek lain dari produk yang sama dengan spesifikasi serupa.(Karuhanga, 2010) Perceived price penting karena mewakili isyarat ekstrinsik dan menawarkan salah satu bentuk informasi terpenting yang tersedia bagi pelanggan ketika membuat keputusan pembelian. (Beneke et al., 2013). Harga yang adil akan menjadi salah satu dasar penilaian dan perbandingan antara harga referensi yang dirasakan pembeli dan harga sebenarnya yang ditetapkan oleh penjual (Babin et al., 2003). Ketika konsumen menganggap harga produk/ jasa adil atau terjangkau, mereka konsumen lebih bersedia untuk membeli produk/ layanan tersebut. Oleh karena itu, perceived price yang positif atas layanan/ produk dapat meningkatkan niat beli konsumen. Perceived price yang baik akan memiliki efek positif secara signifikan terhadap niat beli dibandingkan dengan perceived price yang tidak baik (Mannan et al., 2019). Konsumen akan merasa bahwa harga yang lebih rendah lebih baik daripada harga yang lebih tinggi (Park \& Jang 2019). 
Lailatul Maghfiroh \& Sri Setyo Iriani. Niat Beli Sepatu Merek Lokal oleh Generasi Muda: Pengaruh Consumer Ethnocentrism, Perceived Quality, Perceived Price, dan Perceived Brand Image

\section{Perceived Brand Image}

Perceived brand image adalah persepsi konsumen atas atribut merek tertentu dan merupakan komponen penting dari ekuitas merek. Perceived brand image memiliki efek langsung dan tidak langsung pada niat beli, sehingga terdapat hubungan yang signifikan dan positif antara citra merek dan niat membeli merek (Yu et al., 2018).

Perceived brand image merupakan faktor penting yang mempengaruhi persepsi subjektif pelanggan dan perilaku konsekuen. Perceived brand image didefinisikan sebagai sekumpulan persepsi tentang merek seperti yang tercermin dari asosiasi merek yang disimpan dalam memori konsumen. Perceived brand image yang lebih kuat mengarah pada niat beli yang lebih positif terhadap produk bermerek dan atributnya. Serupa dengan perceived quality, perceived brand image akan berkorelasi positif dengan etnosentrisme konsumen di negara maju karena produk dalam negeri dikaitkan dengan perceived brand image yang tinggi dalam banyak situasi. Perceived brand image memengaruhi kesediaan konsumen untuk membeli terlepas dari apakah produk itu dalam negeri atau impor. Semakin besar perceived brand image produk dalam negeri maka semakin besar pula kemauan untuk membelinya (Yen, 2018).

\section{Hubungan antar Variabel}

Konsumen etnosentris tinggi, dibandingkan dengan individu dengan tingkat etnosentrisme konsumen yang rendah, memiliki sikap yang lebih baik terhadap produk dari negara mereka sendiri. Oleh karena itu, hubungan antara etnosentrisme konsumen dan niat beli produk dalam negeri berkorelasi positif di negara berkembang (Yen, 2018). Menurut Fernández-Ferrín et al. (2015), konsumen yang memiliki etnosentrisme yang tinggi lebih memilih untuk membeli produk dalam negeri daripada produk luar negeri dan melihat produk dalam negeri lebih unggul daripada yang diproduksi di negara lain. Hasil penelitian Zebal \& Jackson (2019) juga menyatakan bahwa semakin tinggi etnosentrisme konsumen, semakin besar niat beli terhadap produk lokal.

H1: Terdapat pengaruh positif antara consumer ethnocentrism terhadap niat beli.

Hal penting yang dapat memicu niat beli produk adalah kualitas yang dirasakan karena konsumen ingin membeli produk yang berkualitas. Maka perceived quality berpengaruh positif terhadap niat beli konsumen (Yan et al., 2019). Konsumen mungkin akan bersedia membeli produk dalam negeri jika mereka menganggapnya berkualitas tinggi. Dengan demikian, dapat diasumsikan bahwa perceived quality akan berdampak positif pada niat beli produk lokal bagi konsumen di negara berkembang (Yen, 2018). Hubungan antara perceived quality dan niat beli konsumen telah diselidiki secara ekstensif bahwa ada hubungan positif antara keduanya (Souiden et al., 2018).

H2: Terdapat pengaruh positif antara perceived quality terhadap niat beli.

Harga merupakan biaya yang paling ditentukan oleh konsumen dan berperan penting dalam pengambilan keputusan pembelian (Park \& Jang, 2019). Ketika konsumen menganggap harga produk/ jasa adil, atau terjangkau, mereka lebih bersedia untuk membeli produk/ layanan tersebut. Oleh karena itu, perceived price yang positif atas layanan/ produk dapat meningkatkan niat beli (Babin et al., 2003). Perceived price yang baik akan memiliki efek positif secara signifikan terhadap niat beli konsumen, dibandingkan dengan perceived price yang tidak baik (Mannan et al., 2019).

H3: Terdapat pengaruh positif antara perceived price terhadap niat beli.

Perceived brand image merupakan faktor penting yang memengaruhi persepsi subjektif pelanggan dan perilaku konsekuen. Perceived brand image yang lebih kuat mengarah pada niat beli yang lebih positif terhadap produk bermerek dan atributnya. Perceived brand image memengaruhi niat beli konsumen terlepas dari apakah produk itu dalam negeri atau impor. Semakin baik perceived brand image produk dalam negeri maka semakin besar pula niat belinya (Yen, 2018). Dalam penelitian Lee \& Lee (2018), perceived brand image memiliki pengaruh positif pada kualitas dan nilai produk yang dipersepsikan, dan secara positif mempengaruhi niat beli. Yu et al., (2018) juga menyatakan dalam 
hasil penelitiannya bahwa terdapat hubungan yang signifikan dan positif antara perceived brand image dan niat beli. Adapun kerangka berpikir yang dibuat untuk mengetahui hubungan antarvariabel digambarkan pada gambar 1.

H4: Terdapat pengaruh positif antara perceived brand image terhadap niat beli.

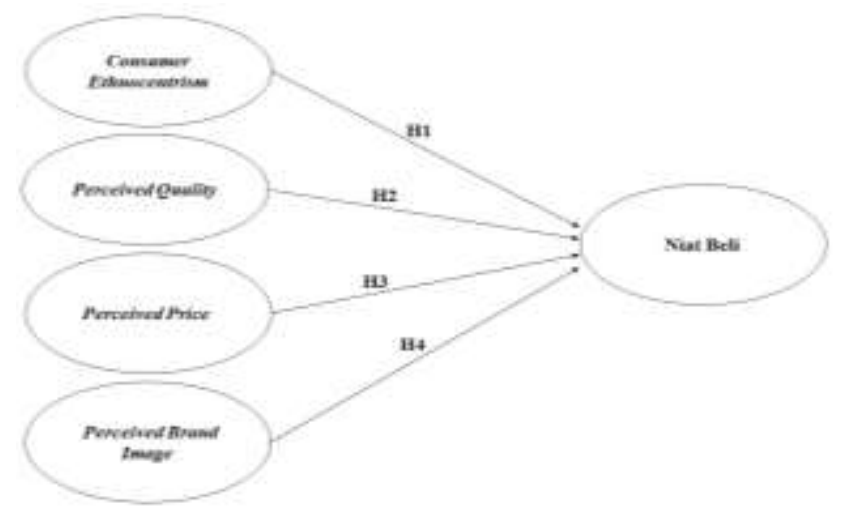

\section{Gambar 1. RANCANGAN PENELITIAN}

\section{METODE PENELITIAN}

Jenis penelitian ini adalah penelitian konklusif. Penelitian ini juga menggunakan jenis penelitian kausal yang bertujuan untuk mendapatkan bukti hubungan sebab-akibat (Malhotra et al., 2017). Teknik analisis data yang digunakan penelitian ini adalah regresi linier berganda yang digunakan untuk menganalisis hubungan secara linear antara dua atau lebih variabel independen atau variabel bebas yakni berupa consumer ethnocentrism, perceived quality, perceived price dan perceived brand image terhadap variabel terikat yakni niat beli sepatu merek lokal. Jenis data yang digunakan yaitu data kuantitatif berupa angka yang terukur, rasional, dan sistematis. Sumber data dalam penelitian ini berupa data primer berupa hasil angket pada responden melalui Google Form yang berupa 7 pertanyaan untuk variabel consumer ethnocentrism, 10 pertanyaan untuk variabel perceived quality, 4 pertanyaan untuk variabel perceived price, 11 pertanyaan untuk variabel perceived brand image, dan 3 pertanyaan untuk variabel niat beli yang diukur menggunakan skala Likert 1-5 (1: sangat tidak setuju, 2: tidak setuju, 3: ragu-ragu, 4: setuju, 5: sangat setuju) dan 3 pertanyan terbuka yang akan dibahas dengan metode statistik deskriptif pada bagian hasil. Data didapat dengan cara menyebarkan link angket secara online yaitu melalui WhatsApp, Instagram dan Line. Populasi dalam penelitian ini adalah responden laki-laki dan perempuan yang tergolong generasi muda yakni berusia antara 15-24 tahun, memiliki ketertarikan terhadap fashion dan mengenal merek Ventela. Adapun jumlah sampel penelitian yang digunakan sebanyak 205 responden. Metode penarikan sampel yang digunakan adalah non-probability sampling dan teknik pengambilan sampel yang digunakan adalah judgemental sampling. Software yang digunakan untuk mengolah data dalam penelitian ini adalah IBM Statistics SPSS versi 26. Butir-butir pernyataan angket dapat dilihat pada tabel 1.

\section{HASIL DAN PEMBAHASAN}

\section{Karakteristik Responden}

Tabel 2 menunjukkan jumlah dan persentase karakteristik responden pada penelitian ini. Sebagian besar responden berusia 19-21 tahun sebanyak 96 orang (47\%). Berdasarkan jenis kelamin, responden paling banyak berjenis kelamin perempuan yaitu 139 orang $(68 \%)$. Rata-rata responden memiliki pengeluaran perbulan sebesar <Rp1.000.000 sebanyak 119 orang (58\%). Mayoritas responden berstatus belum menikah dengan jumlah 200 orang (98\%). Pendidikan responden paling banyak adalah SMA Sederajat yaitu sebesar 155 orang $(75 \%)$. 
Lailatul Maghfiroh \& Sri Setyo Iriani. Niat Beli Sepatu Merek Lokal oleh Generasi Muda: Pengaruh Consumer Ethnocentrism, Perceived Quality, Perceived Price, dan Perceived Brand Image

\section{Tabel 1.}

\section{BUTIR-BUTIR PERNYATAAN ANGKET}

\begin{tabular}{|c|c|c|}
\hline Variabel & Butir-Butir Pernyataan & Sumber \\
\hline $\begin{array}{l}\text { Consumer } \\
\text { Ethnocentrsim }\end{array}$ & $\begin{array}{l}\text { Saya lebih memilih sepatu buatan dalam negeri dibandingkan sepatu } \\
\text { buatan luar negeri. } \\
\text { Saya lebih memilih sepatu buatan dalam negeri karena akan } \\
\text { mendukung bisnis dalam negeri. } \\
\text { Saya lebih memilih sepatu buatan dalam negeri karena akan } \\
\text { meminimalkan pengangguran. } \\
\text { Saya lebih memilih membeli sepatu buatan dalam negeri agar negara } \\
\text { lain tidak menjadi lebih kaya. } \\
\text { Saya lebih suka membeli sepatu merek lokal meskipun memunculkan } \\
\text { biaya yang lebih mahal. } \\
\text { Menurut Saya, sepatu merek luar negeri tidak boleh dipasarkan di } \\
\text { Indonesia. } \\
\text { Menurut Saya, sepatu merek luar negeri harus membayar pajak lebih } \\
\text { tinggi agar tidak banyak masuk ke Indonesia. }\end{array}$ & $\begin{array}{l}\text { Diadopsi dari Yen } \\
\text { (2018), Abdelwahab } \\
\text { et al. (2020) dan } \\
\text { Sun et al. }(2020)\end{array}$ \\
\hline $\begin{array}{l}\text { Perceived } \\
\text { Quality }\end{array}$ & $\begin{array}{l}\text { Ventela adalah sepatu yang elegan. } \\
\text { Ventela adalah sepatu yang menarik. } \\
\text { Ventela adalah sepatu yang berkualitas baik. } \\
\text { Ventela adalah sepatu yang dibuat dari bahan yang berkualitas baik. } \\
\text { Ventela adalah sepatu yang memiliki model yang bagus. } \\
\text { Ventela adalah sepatu yang tahan lama. } \\
\text { Ventela adalah sepatu yang dapat diandalkan. } \\
\text { Kualitas sepatu Ventela konsisten. } \\
\text { Ventela memiliki fitur yang lebih baik dari sepatu sejenis. } \\
\text { Kualitas Ventela sesuai dengan yang dijanjikan. }\end{array}$ & $\begin{array}{l}\text { Diadopsi dari Yen } \\
\text { (2018), Shariq } \\
\text { (2019), Singla \& } \\
\text { Gupta (2019), } \\
\text { Meshreki et al. } \\
\text { (2018) dan Kim et } \\
\text { al. (2017) }\end{array}$ \\
\hline Perceived Price & $\begin{array}{l}\text { Harga Ventela wajar. } \\
\text { Harga Ventela masuk akal. } \\
\text { Harga Ventela sesuai dengan produknya. } \\
\text { Harga Ventela lebih terjangkau dibandingkan sepatu merek lain. }\end{array}$ & $\begin{array}{l}\text { Diadopsi dari } \\
\text { (Karuhanga, 2010) } \\
\text { dan Mannan } \text { et al. } \\
\text { (2019) }\end{array}$ \\
\hline $\begin{array}{l}\text { Perceived } \\
\text { Brand Image }\end{array}$ & $\begin{array}{l}\text { Ventela adalah merek yang fashionable. } \\
\text { Ventela adalah merek yang memiliki reputasi yang baik. } \\
\text { Ventela adalah merek yang memiliki reputasi kualitas yang baik. } \\
\text { Ventela adalah merek yang elegan. } \\
\text { Ventela adalah merek yang memiliki model yang up to date. } \\
\text { Ventela adalah merek yang terkenal. } \\
\text { Ventela adalah merek yang andal (dapat dipercaya). } \\
\text { Ventela adalah merek yang unik. } \\
\text { Ventela adalah merek yang memiliki kualitas yang baik. } \\
\text { Ventela adalah merek yang menunjukkan simbol status sosial. } \\
\text { Ventela adalah merek yang menarik. }\end{array}$ & $\begin{array}{l}\text { Diadopsi dari Yen } \\
\text { (2018), Ismail \& } \\
\text { Spinelli (2012) dan } \\
\text { Nyadzayo et al. } \\
(2020)\end{array}$ \\
\hline Niat Beli & $\begin{array}{l}\text { Saya akan membeli Ventela karena Ventela adalah produk buatan } \\
\text { dalam negeri. } \\
\text { Saya akan membeli Ventela }\end{array}$ & $\begin{array}{l}\text { Diadopsi dari Yen } \\
\text { (2018), Son \& Jin } \\
\text { (2019), Lomelí et al. } \\
\text { (2019), Teng } \\
\text { (2019) dan Kim et } \\
\text { al. (2017) }\end{array}$ \\
\hline
\end{tabular}

Sumber: Data Diolah

\section{Uji Asumsi Klasik}

Uji asumsi klasik terdiri atas uji validitas, reliabilitas, normalitas, multikolinearitas, dan heteroskedastisitas. Hasil dari uji validitas semua variabel menunjukkan bahwa nilai $r$ hitung $>r$ tabel $(0,30)$ yang dapat diartikan bahwa semua pernyataan pada angket dinyatakan valid. Sedangkan hasil dari Uji reliabilitas semua variabel menunjukkan bahwa nilai cronbach's alpha lebih besar dari 0,70 yang dapat diartikan bahwa semua pernyataan pada angket dinyatakan reliabel. Selanjutnya, pada uji 
normalitas, model menenuhi asumsi normalitas karena nilai signifikansi uji kolmogorov-smirnov yakni nilai monte carlo sig. (2-tailed) $>0,05$, yaitu sebesar 0,054 .

Tabel 2.

KARAKTERISTIK RESPONDEN

\begin{tabular}{llcc}
\hline \multicolumn{1}{c}{ Karakteristik Responden } & Frekuensi & Persentase (\%) \\
\hline Mengetahui Merek & Ya & 205 & $100 \%$ \\
Ventela & Tidak & - & - \\
Usia & $<15$ tahun & - & - \\
& $15-18$ tahun & 19 & $9 \%$ \\
& $19-21$ tahun & 96 & $47 \%$ \\
& $22-24$ tahun & 90 & $44 \%$ \\
Jenis Kelamin & $>24$ tahun & - & - \\
Pengeluaran Per & Laki-laki & 66 & $32 \%$ \\
Bulan & Perempuan & 139 & $68 \%$ \\
& <p1.000.000 & 119 & $58 \%$ \\
& Rp1.000.000 - Rp2.000.000 & 61 & $30 \%$ \\
Status & Rp2.000.000 - Rp3.000.000 & 14 & $7 \%$ \\
& Rp3.000.000 - Rp4.000.000 & 7 & $3 \%$ \\
Pendidikan & $>$ Rp4.000.000 & 4 & $2 \%$ \\
& Menikah & 5 & $2 \%$ \\
& Belum Menikah & 200 & $98 \%$ \\
& SD Sederajat & - & - \\
& SMP Sederajat & 2 & $1 \%$ \\
& SMA Sederajat & 155 & $75 \%$ \\
& Diploma & 9 & $4 \%$ \\
& S1 & 39 & $20 \%$ \\
& S2 & - & - \\
\hline Total & S3 & - & - \\
\hline
\end{tabular}

Sumber: Data Diolah

Nilai tolerance dari consumer ethnocentrism yaitu $0,809 \geq 0,1$ dan nilai VIF sebesar 1,236 , nilai tolerance perceived quality yaitu $0,366 \geq 0,1$ dan nilai VIF sebesar 2,736, nilai tolerance perceived price yaitu $0,859 \geq 0,1$ dan nilai VIF sebesar 1,164 , nilai tolerance perceived brand image yaitu $0,343 \geq 0,1$ dan nilai VIF sebesar 1,916. Artinya, model memenuhi asumsi multikolienaritas karena nilai tolerance pada semua variabel memiliki nilai lebih dari 0,10 dan nilai VIF pada semua variabel kurang dari 10. Lebih lanjut, asumsi heteroskedastisitas terpenuhi karena tidak terdapat pola yang jelas pada grafik scatterplots serta titik-titik menyebar di atas dan di bawah angka 0 pada sumbu Y. Hal ini berarti tidak ada gejala heteroskedastisitas.

\section{Hasil Regresi Linier Berganda}

Berdasarkan hasil uji t pada Tabel 3, H1-H3 berhasil dibuktikan karena nilai signifikansi < 0,05. Artinya, variabel consumer ethnocentrism (X1) berpengaruh secara signifikan terhadap niat beli (Y), variabel perceived quality $(\mathrm{X} 2)$ berpengaruh secara signifikan terhadap niat beli (Y), dan variabel perceived price $(\mathrm{X} 3)$ berpengaruh secara signifikan terhadap niat beli $(\mathrm{Y})$. $\mathrm{H} 4$ gagal dibuktikan karena nilai signifikansi sebesar 0,411>0,05. Artinya, variabel perceived brand image (X4) tidak memiliki pengaruh secara signifikan terhadap niat beli $(\mathrm{Y})$.

\section{Hasil Pertanyaan Terbuka}

Selain pertanyaan utama, pada angket penelitian terdapat pertanyaan-pertanyaan terbuka. Jawaban dari pertanyaan terbuka tersebut dianalisis secara deskriptif untuk lebih dapat memahami bagaimana perspektif responden atas pertanyaan yang diajukan. 
Lailatul Maghfiroh \& Sri Setyo Iriani. Niat Beli Sepatu Merek Lokal oleh Generasi Muda: Pengaruh Consumer Ethnocentrism, Perceived Quality, Perceived Price, dan Perceived Brand Image

Gambar 2 menunjukkan jawaban responden terkait pertanyaan "Apakah Anda mendukung produk dalam negeri?" bahwa sebanyak 1 responden $(0,5 \%)$ menjawab sangat tidak mendukung, 0 responden (0\%) menjawab tidak mendukung, 2 responden (1\%) menjawab ragu-ragu, 34 responden (17\%) menjawab mendukung, 165 responden (80\%) menjawab sangat mendukung, dan 3 responden $(1,5 \%)$ tidak memberi jawaban. Berdasarkan Gambar 2 dapat diasumsikan bahwa kebanyakan responden sangat mendukung produk-produk dalam negeri.

Tabel 3.

HASIL REGRESI LINIER BERGANDA

\begin{tabular}{lccccc}
\hline \multicolumn{1}{c}{ Model } & \multicolumn{2}{c}{$\begin{array}{c}\text { Unstandardized } \\
\text { Coefficients } \\
\text { B }\end{array}$} & $\begin{array}{c}\text { Standardized } \\
\text { Coefficients } \\
\text { Beta }\end{array}$ & t Error & Sig. \\
\hline (Constant) & $-1,228$ & 0,874 & & $-1,405$ & 0,161 \\
Consumer_Ethnocentrism & 0,08 & 0,023 & 0,191 & 3,528 & 0,001 \\
Perceived_Quality & 0,146 & 0,03 & 0,39 & 4,845 & 0 \\
Perceived_Price & 0,256 & 0,042 & 0,324 & 6,159 & 0 \\
Perceived_Brand_Image & 0,025 & 0,03 & 0,068 & 0,824 & 0,411 \\
\hline
\end{tabular}

Sumber: Output IBM Statistics 26

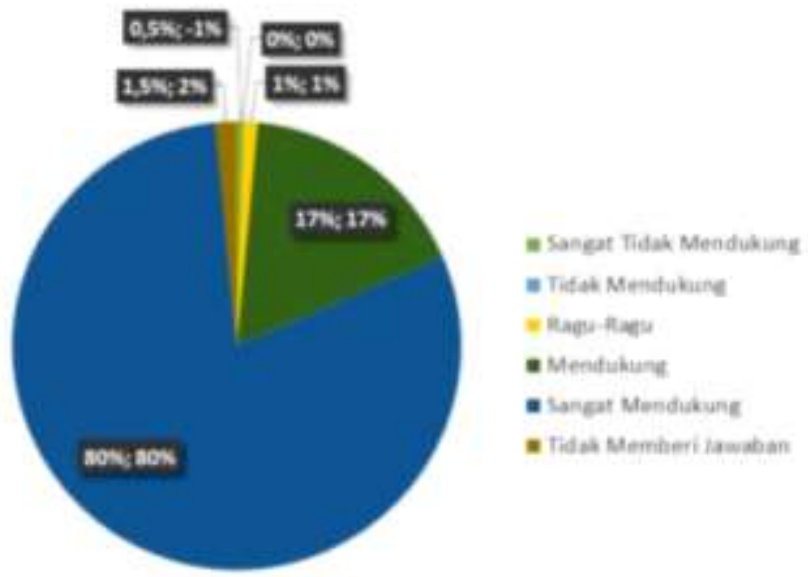

Sumber: Data Diolah

\section{Gambar 2. DUKUNGAN GENERASI MUDA TERHADAP PRODUK DALAM NEGERI}

Perspektif konsumen terkait produk dalam negeri yang ditunjukkan pada Gambar 3(a), terdapat respon positif dan negatif yang diberikan oleh responden terkait pertanyaan "Bagaimana menurut Anda terkait produk dalam negeri?" yang menunjukkan hasil bahwa respon positif memiliki nilai sebesar 21\% untuk kualitas, 6\% untuk harga, 4\% untuk kreatifitas dan keunikan, 22\% untuk perkembangan industri yang semakin baik, $13 \%$ untuk kemampuan bersaing dengan produk asing, $1 \%$ untuk dukungan terhadap bisnis dalam negeri, $2 \%$ untuk dukungan terhadap perekonomian negara, $4 \%$ untuk nasionalisme, $3 \%$ untuk dukungan dalam upaya mengurangi pengangguran, dan $3 \%$ untuk keterjangkauan produk. Sedangkan nilai respon negatif untuk kualitas sebesar 2\%, harga sebesar 3\%, kreatifitas dan keunikan sebesar 3\%, promosi sebesar 6\%, butuhnya dukungan yang lebih besar sebesar $2 \%$, citra produk asing lebih baik sebesar 3\%, dan kebencian atas merek tertentu sebesar $2 \%$.

Gambar 3(b) menunjukkan jawaban dari pertanyaan terkait alasan yang mendasari generasi muda atas pembelian produk dalam negeri yang meliputi kualitas dengan nilai sebesar 19\%, harga dengan nilai sebesar $18 \%$, kreatifitas dan keunikan dengan nilai sebesar 6\%, perkembangan insdustri yang semakin baik dengan nilai sebesar 5\%, kemampuan bersaing dengan produk asing dengan nilai sebesar 2\%, dukungan terhadap bisnis dalam negeri dengan nilai sebesar $12 \%$, dukungan terhadap perekonomian negara dengan nilai sebesar $12 \%$, nasionalisme dengan nilai sebesar $20 \%$, dukungan dalam upaya 
mengurangi pengangguran dengan nilai sebesar 4\%, dan keterjangkauan produk dengan nilai sebesar $2 \%$.

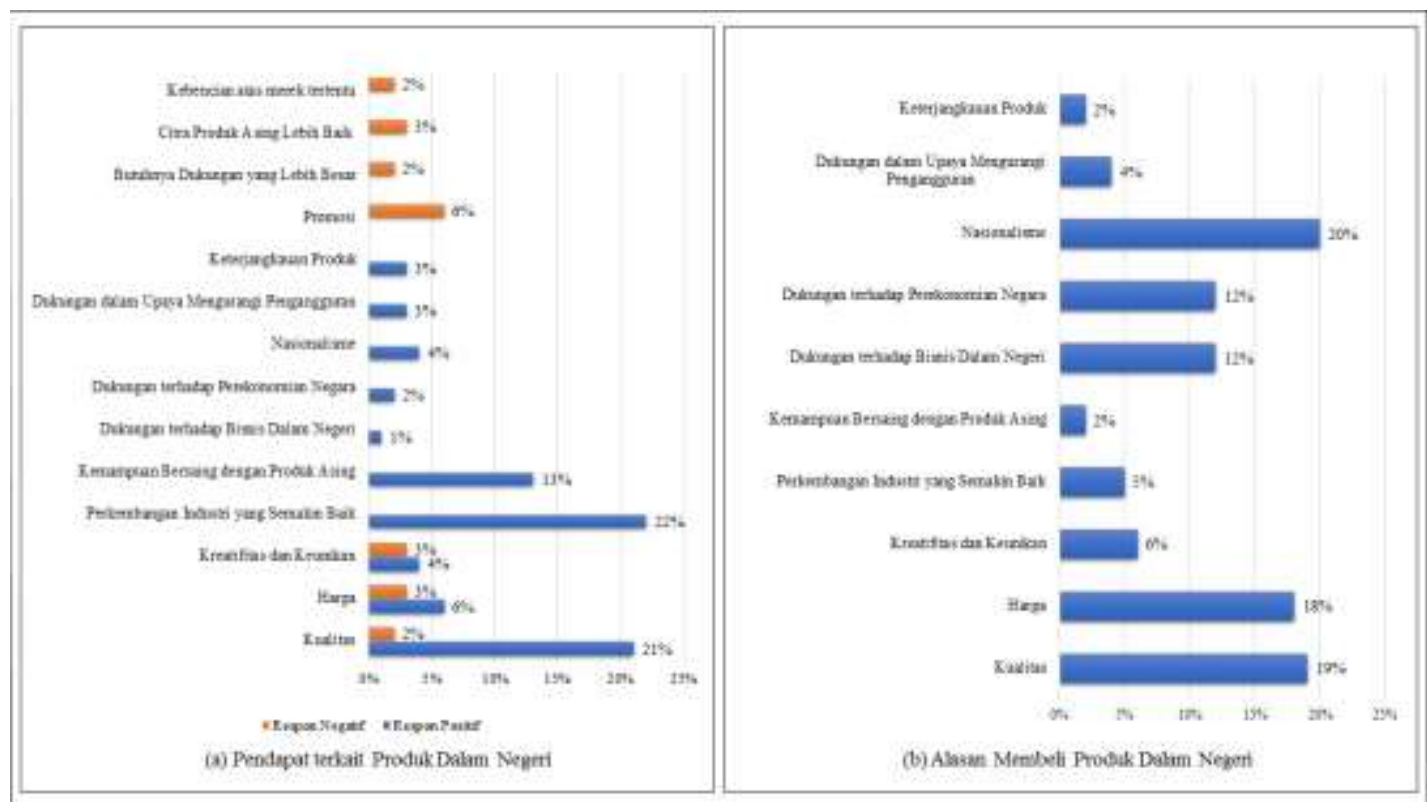

Sumber: Data Diolah

\section{Gambar 3. PERSPEKTIF GENERASI MUDA TERKAIT PRODUK DALAM NEGERI}

\section{Pengaruh Consumer Ethnocentrism terhadap Niat Beli}

Hasil penelitian menunjukkan bahwa terdapat pengaruh consumer ethnocentrism terhadap niat beli secara signifikan. Salah satu faktor yang mempengaruhi niat beli adalah consumer ethnocentrism. Penelitian ini mendukung penelitian Yen (2018) yang mengemukakan bahwa consumer ethnocentrism berpengaruh signifikan terhadap niat beli, sehingga hipotesis pertama didukung. Selain itu, hal ini juga mendukung penelitian Fernández-Ferrín et al., (2015) dan Zebal \& Jackson (2019). Consumer ethnocentrism sangat relevan ketika konsumen memilih antara produk dalam negeri dan impor luar negeri. Niat beli juga dipengaruhi oleh animo konsumen atas produk atau merek yang diproduksi oleh negara produsen tertentu (Cui et al., 2012). Sehingga, kemauan membeli produk lokal juga akan terpengaruh kecintaan atas negara sendiri. Banyaknya sepatu lokal dan asing yang dijual di Indonesia memberikan banyak preferensi untuk konsumen dalam memilih sepatu. Maka, konsumen dengan etnosentrisme yang tinggi akan cenderung memilih sepatu lokal, salah satunya Ventela. Dalam sudut pandang perekonomian, larangan memasarkan produk asing di dalam negeri akan berdampak pada iklim bisnis di Indonesia. Di sisi lain, adanya produk asing di pasar Indonesia maka akan meningkatkan persaingan bisnis produk-produk di Indonesia. Produsen-produsen di Indonesia cukup kreatif dan kompetitif dalam memproduksi suatu produk sehingga dapat bersaing dengan produk asing yang berada di Indonesia serta menarik minat beli generasi muda yang menyukai produk yang unik dan kekinian. Selain itu, pemerintah juga dapat menyelenggarakan program-program yang dapat meningkatkan kecintaan pemuda terhadap produk dalam negeri. Hal ini akan meningkatkan kecintaan pemuda terhadap bangsanya dan juga membantu pemasaran produk lokal.

\section{Pengaruh Perceived Quality terhadap Niat Beli}

Pengaruh perceived quality terhadap niat beli dinyatakan berpengaruh positif secara signifikan. Hasil penelitian ini memperkuat hasil penelitian Yen (2018) yang mengemukakan bahwa perceived quality berpengaruh signifikan terhadap niat beli serta penelitian Souiden et al., (2018) dan Yan et al. (2019) yang mengemukakan hal serupa. Responden penelitian menyatakan bahwa produk dalam negeri memiliki kualitas yang dapat bersaing dengan produk asing. Kualitas juga menjadi salah satu alasan responden untuk membeli produk dalam negeri. Responden menyarankan supaya usaha dalam negeri mampu mempertahankan dan meningkatkan kualitas produknya menjadi lebih baik lagi. Tetapi, terdapat pula responden yang menganggap produk-produk dalam negeri masih kurang baik dan perlu 
perbaikan kualitas. Bila dibandingkan dengan sepatu sejenis, Ventela memiliki perbedaan yang tidak terlalu signifikan. Artinya, konsumen tidak dapat membedakan fitur-fitur Ventela dengan sepatu sejenis. Produsen sepatu merek lokal diharapkan menjaga konsistensi dan meningkatkan kualitas produknya. Pemasar juga diharapkan mampu mengomunikasikan manfaat dan keunikan produk lokal untuk mendapat perhatian dari konsumen.

\section{Pengaruh Perceived Price terhadap Niat Beli}

Perceived price berpengaruh positif secara signifikan terhadap niat beli. Penelitian ini sesuai dengan hasil penelitian Park \& Jang (2019) dan Babin et al., (2003) yang mengemukakan bahwa Perceived Price berpengaruh signifikan terhadap niat beli. Dalam penelitian Mannan et al., (2019), niat beli tidak hanya dipengaruhi oleh perceived price, tetapi juga oleh perceived eWOM credibility dan perceived information quality. Harga adalah faktor penting yang menentukan pembelian konsumen. Tetapi, keadilan dan persepsi harga lebih diperhatikan. Biasanya harga yang lebih murah akan meningkatkan kemauan konsumen untuk membeli. Generasi muda cenderung memilih produk yang berkualitas baik dengan harga yang lebih murah dibandingkan harga yang lebih mahal. Generasi muda memiliki perilaku yang konsumtif, selalu menginginkan apa yang orang lain miliki dan memiliki keinginan yang lebih besar dari pada kebutuhan. Sehingga, produk dengan harga murah dan berkualitas baik sangat cocok untuk memenuhi niat beli generasi muda. Dalam pertanyaan terbuka pada angket penelitian ini, responden memberikan jawaban positif terkait harga bahwa produk-produk di Indonesia memiliki harga yang lebih murah apabila dibandingkan dengan produk merek asing. Responden menjawab bahwa produk dalam negeri mudah didapatkan karena produk di jual di dalam wilayah negara sendiri sehingga biaya pengiriman lebih murah. Tetapi, sebagian responden menganggap bahwa beberapa produk di Indonesia memiliki harga yang lebih mahal dibandingkan produk asing yang memiliki harga yang lebih murah di Indonesia. Salah satu hal yang memengaruhinya adalah biaya produksi yang berdampak pada harga jual produk. Ventela dijual dalam kisaran harga 200-300 ribuan dan tergolong sepatu lokal dengan harga terjangkau sehingga cocok dipasarkan pada konsumen Indonesia, mengingat Indonesia adalah negara berkembang yang penduduknya lebih memilih membeli produk yang lebih murah dari pada produk dalam negeri yang lebih mahal.

\section{Pengaruh Perceived Brand Image terhadap Niat Beli}

Penelitian ini gagal membuktikan pengaruh perceived brand image terhadap niat beli. Sehingga hal ini tidak sesuai dengan penelitian yang didukung oleh oleh Yen (2018), Lee \& Lee (2018) dan Yu et al., (2018) yang mengemukakan bahwa perceived brand image berpengaruh positif terhadap niat beli. Perceived brand image bukanlah hal utama yang mendasari konsumen ketika akan membeli sepatu. Ketika akan membeli sepatu, konsumen tidak hanya akan melihat sepatu berdasarkan merek, tetapi juga kualitas dan fungsi sepatu. Meskipun sepatu dengan merek yang baik akan dapat merepresentasikan dirinya, tetapi, sepatu dengan kualitas, fungsi, visual, dan desain yang bagus yang baik akan dapat memicu niat beli konsumen meskipun mereknya kurang dikenal. Meskipun responden sudah mengenal Ventela, tetapi perceived brand image yang dimiliki Ventela masih kalah dibandingkan sepatu yang beredar di pasar. Hal ini juga sesuai dengan karakteristik generasi muda yang selalu mengikuti perkembangan tren, menyukai banyak aksesoris untuk menunjang penampilan dan suka bereksplorasi sehingga tidak terlalu mengedepankan merek. Anna (2017) menyatakan bahwa generasi muda menunjukkan diri melalui penampilan sehingga memiliki anggaran untuk belanja produk fashion. Mereka memilih produk yang memiliki makna dan kesan daripada terpaku pada suatu merek terkenal yang produknya kurang evolutif.

Dalam pertanyan terbuka yang dicantumkan dalam angket penelitian ini, responden memberikan jawaban bahwa produk-produk Indonesia variatif, unik, khas, memiliki visual yang bagus dan kreatif. Di sisi lain, responden menganggap bahwa apabila konsumen memiliki kebencian atas merek lokal tertentu, maka akan berpengaruh pada tingkat dukungan terhadap merek lokal dan kecenderungan mendukung merek asing, termasuk pada kemauannya membeli Ventela. Selain itu, beberapa produk Indonesia dianggap memiliki kemiripan dengan produk asing sehingga terkesan menjiplak dan meniru. Berdasarkan hal itu, produk-produk Indonesia perlu menciptakan inovasi dan perbaikan dalam ekuitas produknya sehingga akan membangun ciri khas tersendiri. Sebagian masyarakat 
memiliki pola pikir bahwa produk lokal tidak lebih bagus/ menarik dibandingkan dengan produk merek asing. Hal ini menyebabkan produk lokal tidak didukung dengan maksimal. Masyarakat masih menganggap bahwa produk asing adalah lebih baik dan produk dalam negeri masih membutuhkan kepercayaan dari masyarakat lokal.

Perceived brand image juga dipengaruhi oleh kelompok acuan. Dalam konteks sepatu Ventela, kelompok acuan melibatkan public figure di Indonesia. Ventela Sang Sekerta Lohita merupakan varian Ventela yang bercorak batik hasil kolaborasi Ventela dengan Kaesang Pangarep dan Never Too Lavish. Presiden Jokowi melakukan unboxing sepatu lokal untuk pertama kali yang videonya diunggah dalam akun Never Too Lavish yang memikat para pecinta sneakers, terutama pecinta sneakers lokal (Prihatin, 2020). Selain itu, Presiden Jokowi juga mengenakan Ventela Sang Sekerta Lohita yang bercorak merah, hitam dan putih yang sempat mencuri perhatian penggemar snakers di kalangan anak muda (Wisnubrata, 2020). Dalam perilaku konsumen, kelompok acuan akan memberikan informasi, standar dan nilai yang akan memengaruhi perilaku seseorang. Kelompok acuan memberikan kesaksian, dorongan dan penguatan, pengaruh dalam pemasaran produk yang dapat memperkuat kredibilitas yang dimiliki dan memengaruhi persepsi konsumen (Sumarwan, 2015).

\section{Perspektif Generasi Muda terhadap Produk Dalam Negeri}

Responden menyatakan bahwa perkembangan bisnis lokal di Indonesia semakin berkembang. Hal ini berlaku dalam berbagai sektor produk, salah satunya adalah sepatu dan barang-barang fashion lainnya. Di sisi lain, produk fashion lokal memiliki peminat yang semakin banyak dari tahun ke tahun dan memiliki model yang up to date. Dengan perkembangan yang terjadi, menciptakan kemampuan bersaing dengan produk asing. Produk dalam negeri memiliki kualifikasi yang baik sehingga mampu bersaing dengan produk asing yang beredar di dalam negeri. Bahan yang digunakan untuk membuat produk tidak kalah dengan bahan yang digunakan oleh produk merek asing, sehingga produk yang dihasilkan tidak jauh berbeda. Kemauan membeli produk-produk Indonesia merupakan wujud dukungan terhadap bisnis dalam negeri karena mampu membuat bisnis dalam negeri semakin berkembang dan mampu bersaing dengan produk luar negeri. Hal ini juga berdampak baik pada: perekonomian negara, di mana berkembangnya bisnis dalam negeri maka akan mampu menyumbang pendapatan negara dan mendukung pembangunan ekonomi negara; dan berkurangnya pengangguran, di mana berkembangnya bisnis dalam negeri dapat menekan angka pengangguran, karena ketika bisnis dalam negeri semakin berkembang maka akan membutuhkan tenaga kerja. Berdasarkan hal itu, maka para pencari kerja atau pengangguran dapat dipekerjakan. Tetapi, salah satu hal yang harus diperhatikan dalam upaya mengembangkan bisnis dalam negeri adalah promosi. Responden memberikan respons bahwa merek-merek produk dalam negeri masih kurang dikenal secara luas, sehingga banyak konsumen yang tidak mengetahui atau mengenali. Salah satu penyebabnya adalah masih kurangnya promosi yang dilakukan oleh merek-merek tertentu. Hal ini juga perlu memerhatikan terkait posisi siklus hidup produk dan kesadaran masyarakat itu sendiri. Dalam lain hal, produk-produk dalam negeri masih memerlukan dukungan dari banyak pihak agar semakin berkembang dan menjadi kebanggan. Salah satunya adalah butuhnya dukungan yang lebih besar dari pemerintah yang akan membangun kepercayaan dan kepercayaan diri masyarakat terhadap produk dalam negeri.

\section{KESIMPULAN}

Consumer ethnocentrism terbukti berpengaruh secara signifikan terhadap niat beli, perceived quality berpengaruh secara signifikan terhadap niat beli, perceived price berpengaruh secara signifikan terhadap niat beli, dan perceived brand image tidak memiliki pengaruh secara signifikan terhadap niat beli. Variabel yang digunakan dalam penelitian ini dapat digunakan sebagai pembanding dalam penelitian selanjutnya. Hasil dari penelitian ini dapat digunakan sebagai masukan untuk Ventela dalam menghadapi persaingan bisnis dan perkembangan usaha dengan memerhatikan pengaruh consumer ethnocentrism, perceived quality, perceived price dan perceived brand image terhadap niat 
Lailatul Maghfiroh \& Sri Setyo Iriani. Niat Beli Sepatu Merek Lokal oleh Generasi Muda: Pengaruh Consumer Ethnocentrism, Perceived Quality, Perceived Price, dan Perceived Brand Image

beli pada Ventela. Penelitian selanjutnya disarankan membandingkan beberapa merek fashion lokal dengan positioning yang berbeda.

\section{DAFTAR PUSTAKA}

Abdelwahab, D., Jiménez, N. H., San-Martín, S., \& Prodanova, J. (2020). Between love and boycott: a story of dual origin brands. Spanish Journal of Marketing - ESIC, ahead-of-p(ahead-of-print). https://doi.org/10.1108/sjme-12-2019-0105

Alaydrus, H. (2021). Didukung Pemerintah, Hari Belanja Brand Lokal Bakal Digelar 5 Mei 2021. Retrieved June 10, 2021, from https://ekonomi.bisnis.com/read/20210415/12/1381731/didukung-pemerintah-hari-belanjabrand-lokal-bakal-digelar-5-mei-2021

Anggraini, M. (2020). 15 Jenis-jenis Sepatu yang Banyak Digunakan, Perhatikan untuk Menunjang Penampilan Retrieved April 29, 2021, from https://m.merdeka.com/trending/15-jenis-jenissepatu-yang-banyak-digunakan-perhatikan-untuk-menunjang-penampilan-kln.html?page=all

Anna, L. K. (2017). Gaya Belanja Milenial, Menyukai Produk yang Punya Cerita. Retrieved June 13, 2021, from https://amp.kompas.com/lifestyle/read/2017/12/11/071500720/gaya-belanjamilenial-menyukai-produk-yang-punya-cerita

Anteraja, S. (2020). 13 Brand Sepatu Sneakers Lokal Berkualitas dan Terbaik 2021. Retrieved April 29, 2021, from https://blog.anteraja.id/brand-sepatu-lokal-terbaik/

Aris. (2021). Brand Sepatu Lokal Terbaik Saat Ini Untuk Tampil Keren. Retrieved April 29, 2021, from https://koran-jakarta.com/brand-sepatu-lokal-terbaik-saat-ini-untuk-tampil-keren

Asshidin, N. H. N., Abidin, N., \& Borhan, H. B. (2016). Perceived Quality and Emotional Value that Influence Consumer's Purchase Intention towards American and Local Products. Procedia Economics and Finance, 35(October 2015), 639-643. https://doi.org/10.1016/s22125671(16)00078-2

Babin, B. J., Hardesty, D. M., \& Suter, T. A. (2003). Color and shopping intentions: The intervening effect of price fairness and perceived affect. Journal of Business Research, 56(7), 541-551. https://doi.org/10.1016/S0148-2963(01)00246-6

Beneke, J., Flynn, R., Greig, T., \& Mukaiwa, M. (2013). The influence of perceived product quality, relative price and risk on customer value and willingness to buy: A study of private label merchandise. Journal of Product and Brand Management, 22(3), 218-228. https://doi.org/10.1108/JPBM-02-2013-0262

Clow, K. E., \& Baack, D. (2018). Integrated Advertising, Promotion, and Marketing Communications (8th ed.). United Kingdom: Pearson Education Limited 2018.

Cui, A. P., Wajda, T. A., \& Hu, M. Y. (2012). Consumer animosity and product choice: Might price make a difference? Journal of Consumer Marketing, 29(7), 494-506. https://doi.org/10.1108/07363761211275009

Direktorat Jenderal Bea dan Cukai. (2020). Official Website Direktorat Jenderal Bea dan Cukai. Retrieved April 24, 2021, from https://www.beacukai.go.id/berita/siap-siap-aturan-imporbarang-kiriman-terbaru-mulai-berlaku-30-januari-2020.html

Dzikrullah, A. (2019). 4 Alasan Memilih Brand Lokal sebagai Produk Favoritmu . Retrieved June 10, 2021 ,

from 
https://www.kompasiana.com/muhammaddzikrullah/5df72ddd097f3663547ea772/4-alasanmemilih-brand-lokal-sebagai-produk-favoritmu

Fernández-Ferrín, P., Bande-Vilela, B., Klein, J. G., \& Luisa Del Río-Araújo, M. (2015). Consumer ethnocentrism and consumer animosity: Antecedents and consequences. International Journal of Emerging Markets, 10(1), 73-88. https://doi.org/10.1108/IJOEM-11-2011-0102

Firdha, F. (2020). 20 Sepatu Lokal Kece, Ada yang Sudah Ekspor ke Luar Negeri. Retrieved December 28, 2020, from https://www.ussfeed.com/sepatu-lokal/

Hagiworo, H. (2021). Jadi Identitas Milenial, Sneaker Lokal Tak Kalah dengan Merek Impor. Retrieved June 20, 2021, from https://money.kompas.com/read/2021/04/24/170322426/jadiidentitas-milenial-sneaker-lokal-tak-kalah-dengan-merek-impor

Hasibuan, L. (2018). Peminat Sneakers di Indonesia Naik 70\%. Retrieved February 7, 2021, from https://www.cnbcindonesia.com/lifestyle/20180220131649-33-4849/peminat-sneakers-diindonesia-naik-70

Hoskins, J., Verhaal, J. C., \& Griffin, A. (2020). How within-country consumer product (or brand) localness and supporting marketing tactics influence sales performance. European Journal of Marketing. https://doi.org/10.1108/EJM-11-2018-0787

Karuhanga, B. N. (2010). Propensity to buy private label merchandise: The contributory effects of store image, price, risk, quality and value in the cognitive stream. International Journal of Retail \& Distribution Management, 43(1), 43-62. https://doi.org/https://doi.org/10.1108/IJRDM-09-2013-0175

Kementerian Komunikasi dan Informatika. (2020). Dorong Penjualan Produk Lokal, Pemerintah Gelar Kampanye \#SemuanyaAdaDisini. Retrieved June 10, 2021, from https://www.kominfo.go.id/content/detail/27557/dorong-penjualan-produk-lokal-pemerintahgelar-kampanye-semuanyaadadisini/0/berita

Kementerian Luar Negeri Republik Indonesia. (2020). Upaya Meningkatkan Potensi Produk Umkm Indonesia Untuk Memasuki Pasar Dunia. Retrieved June 10, 2021, from https://kemlu.go.id/portal/id/read/1961/berita/upaya-meningkatkan-potensi-produk-umkmindonesia-untuk-memasuki-pasar-dunia

Kementerian Perindustrian Republik Indonesia. (2019a). Kemenperin: Daya Saing Industri Alas Kaki Nasional Terus Menanjak di Kancah Global. Retrieved April 25, 2021, from https://kemenperin.go.id/artikel/20628/Daya-Saing-Industri-Alas-Kaki-Nasional-TerusMenanjak-di-Kancah-Global

Kementerian Perindustrian Republik Indonesia. (2019b). Kemenperin: Indonesia Produsen Alas KakI Terbesar Keempat Di Dunia. Retrieved May 2, 2021, from https://kemenperin.go.id/artikel/20539/Indonesia-Produsen-Alas-KakI-Terbesar-Keempat-DiDunia

Khan, M. A., Ashraf, R., \& Malik, A. (2019). Do identity-based perceptions lead to brand avoidance? A cross-national investigation. Asia Pacific Journal of Marketing and Logistics, 31(4), 10951117. https://doi.org/10.1108/APJML-12-2017-0332

Lee, J., \& Lee, Y. (2018). Effects of multi-brand company's CSR activities on purchase intention through a mediating role of corporate image and brand image. Journal of Fashion Marketing and Management, 22(3), 387-403. https://doi.org/10.1108/JFMM-08-2017-0087 
Lailatul Maghfiroh \& Sri Setyo Iriani. Niat Beli Sepatu Merek Lokal oleh Generasi Muda: Pengaruh Consumer Ethnocentrism, Perceived Quality, Perceived Price, dan Perceived Brand Image

Lee, W. J., Cheah, I., Phau, I., Teah, M., \& Elenein, B. A. (2016). Conceptualising consumer regiocentrism: Examining consumers' willingness to buy products from their own region. Journal of Retailing and Consumer Services, 32, 78-85. https://doi.org/10.1016/j.jretconser.2016.05.013

Lomelí, M. Á. L., Andreu, J. L., \& Criado, J. R. (2019). Local, global and glocal consumer brand relationships $n$ entre marcas de consumo Relaci o locales, globales y glocales. 23(3), 437-459. https://doi.org/10.1108/SJME-10-2018-0046

Malhotra, N. K., Nunan, D., \& Birks, D. F. (2017). Marketing Research : an applied approach. In The Marketing Book: Seventh Edition (5th ed.). United Kingdom: Pearson Education Limited.

Mannan, M., Ahamed, R., \& Zaman, S. B. (2019). Consumers' willingness to purchase online mental health services. Journal of Services Marketing, 33(5), 557-571. https://doi.org/10.1108/JSM05-2018-0163

Mediaini, A. (2020). Serbuan Sepatu Lokal Merajai Pasar Milenial. Retrieved December 29, 2020, from https://mediaini.com/serbuan-sepatu-lokal-merajai-pasar-milenial/

Meshreki, H., Ennew, C., \& Mourad, M. M. (2018). A comparative analysis of dimensions of COO and animosity on industrial buyers' attitudes and intentions. Journal of Product and Brand Management, 27(7), 832-846. https://doi.org/10.1108/JPBM-10-2017-1625

Nor, A. S. (2019). Geliat Industri Sepatu Lokal Menurut BPIPI, League, dan Piero. Retrieved May 5, 2021, from https://www.mainbasket.com/r/4346/geliat-industri-sepatu-lokal-menurut-bpipileague-dan-piero

Park, E. Y., \& Jang, J. M. (2019). The interplay of social responsibility consciousness and evaluation mode in consumers' response toward cause-related marketing-enhanced product. Asia Pacific Journal of Marketing and Logistics, 32(8), 1651-1674. https://doi.org/10.1108/APJML-062019-0413

Prihatin, I. U. (2020). Jokowi Unboxing Sepatu Hasil Kerja Sama Kaesang dan Brand Lokal . Retrieved June 20, 2021, from https://m.merdeka.com/peristiwa/jokowi-unboxing-sepatu-hasilkerja-sama-kaesang-dan-brand-lokal.html

Prince, M., Yaprak, A. N., \& Palihawadana, D. (2019). The moral bases of consumer ethnocentrism and consumer cosmopolitanism as purchase dispositions. Journal of Consumer Marketing, 36(3), 429-438. https://doi.org/10.1108/JCM-11-2017-2432

Roy, R., \& Chau, R. (2011). Consumer-based brand equity and status-seeking motivation for a global versus local brand. Asia Pacific Journal of Marketing and Logistics, 23(3), 270-284. https://doi.org/10.1108/13555851111143213

SepatuSneaker.Com. (2020). Pengertian Sepatu Sneakers - Apa Itu Sneakers. Retrieved December 29, 2020, from https://sepatusneaker.com/blog/sepatu-sneakers-adalah/

Setiawan, S. (2020). Pengertian Fashion-Stylist, Manfaat, Ciri, Faktor, Para Ahli. Retrieved January 3, 2021, from https://www.gurupendidikan.co.id/pengertian-fashion/

Shu, S. T., \& Strombeck, S. (2017). Cometh self-image congruence: a cross-cultural study. Asia Pacific Journal of Marketing and Logistics, 29(3), 538-552. https://doi.org/10.1108/APJML05-2016-0086

Son, J., \& Jin, B. E. (2019). When do high prices lead to purchase intention? Testing two layers of 
moderation effects. Asia Pacific Journal of Marketing and Logistics, 31(5), 1516-1531. https://doi.org/10.1108/APJML-07-2018-0271

Souiden, N., Ladhari, R., \& Chang, L. (2018). Chinese perception and willingness to buy Taiwanese brands: The role of ethnocentrism and animosity. Asia Pacific Journal of Marketing and Logistics, 30(4), 816-836. https://doi.org/10.1108/APJML-09-2017-0203

Srivastava, K., \& Sharma, N. K. (2013). Consumer attitude towards brand extension goods , durable goods and services. 5(3), 177-197. https://doi.org/10.1108/JIBR-07-2012-0057

Sumarwan, U. (2015). Perilaku Konsumen (2nd ed.; R. Sikumbang, Ed.). Bogor: Ghalia Indonesia.

Sun, Y., Cai, H. H., Su, R., \& Shen, Q. (2019). Advantage of low quality in short life cycle products. Asia Pacific Journal of Marketing and Logistics, 32(5), 1038-1054. https://doi.org/10.1108/APJML-03-2019-0148

Teng, W. (2019). Importance of corporate image for domestic brands moderated by consumer ethnocentrism. Journal of Product and Brand Management, 29(3), 257-272. https://doi.org/10.1108/JPBM-09-2018-2020

Teti Silitonga, L. (2018). Pasar Sepatu: Ini Dia Merek yang Jadi Raja Pasar. Retrieved December 29, 2020, from https://ekonomi.bisnis.com/read/20180207/12/735561/pasar-sepatu-ini-dia-merekyang-jadi-raja-pasar-

Top Brand Award. (2020). Sepatu Casual Fase 1 2020. Retrieved January 13, 2021, from https://www.topbrand-award.com/en/2020/01/sepatu-casual-fase-1-2020/

United Nation. (2007). World Youth Report 2007 | United Nations For Youth. Retrieved from https://www.un.org/development/desa/youth/world-youth-report/world-youth-report-2007.html

Wisnubrata. (2020). Pertanyaan Soal Sepatu Merah Presiden Jokowi, Terjawab Sudah. Retrieved June 20, 2021, from https://lifestyle.kompas.com/read/2020/10/05/110503520/pertanyaan-soalsepatu-merah-presiden-jokowi-terjawab-sudah

Xin, L., \& Seo, S. (2019). The role of consumer ethnocentrism, country image, and subjective knowledge in predicting intention to purchase imported functional foods. British Food Journal, 122(2), 448-464. https://doi.org/10.1108/BFJ-05-2019-0326

Yan, L., Xiaojun, F., Li, J., \& Dong, X. (2019). Extrinsic cues, perceived quality, and purchase intention for private labels: Evidence from the Chinese market. Asia Pacific Journal of Marketing and Logistics, 31(3), 714-727. https://doi.org/10.1108/APJML-08-2017-0176

Yen, Y. S. (2018). Extending consumer ethnocentrism theory: the moderating effect test. Asia Pacific Journal of Marketing and Logistics, 30(4), 907-926. https://doi.org/10.1108/APJML-09-20170226

Yu, M., Liu, F., Lee, J., \& Soutar, G. (2018). The influence of negative publicity on brand equity: attribution, image, attitude and purchase intention. Journal of Product and Brand Management, 27(4), 440-451. https://doi.org/10.1108/JPBM-01-2017-1396

Zebal, M. A., \& Jackson, F. H. (2019). Cues for shaping purchase of local retail apparel clothing brands in an emerging economy. International Journal of Retail and Distribution Management, 47(10), 1013-1028. https://doi.org/10.1108/IJRDM-11-2018-0241 